\title{
The Potential Use of Adipose-derived Stem
}

\section{Cells}

Haibo Wu, BNr, MSc; Maria L. Bolick, PhD; Yusheng Liu, MD, MSc

\section{SUMMARY}

The potential use of stem cell-based therapies for the repair and regeneration of different tissues and organs offers a paradigm shift that will give different therapeutic solutions for variety of diseases. The use of either embryonic stem cells (ESCs) or elicited pluripotent stem cells in clinical scenarios is restricted because of cell inability to divide and to technical and ethical concerns within the genetic manipulation of human ESCs, although these cells are, on paper, extremely helpful. Mesenchymal stem cells appear to be a perfect population of stem cells for sensible regenerative medicine, as they are not subjected to a similar kind of restrictions. Recent basic analyses and clinical studies have shown that the utilization of adipose-derived stem cells (ASCs) harvested from animal fat tissue in regenerative medication is not restricted to mesoblastic tissue, but extends to each germ layer and endodermal tissues and organs. Supported by this information, main purpose of this brief review is to summarize and describe the underlying biology of ASCs and their proliferation and differentiation capacities, alongside current diagnostic and clinical knowledge from a range of medical fields relating to the utilization of ASCs in regenerative drugs.

KEYWORDS Adipose-derived stem cells; Regenerative medicine; Therapy potential; Pluripotential; Proliferation

Sci Insigt. 2018; 2018:e000071. doi:10.15354/si.18.re022
Author Affiliations: Author affiliations are listed at the end of this article.

Correspondence to:

Dr. Yusheng Liu, MD, MSc, Department of Anesthesiology, Obstetrics and Gynecology Hospital, Affiliated to Nanjing Medical University, Nanjing, China. E-mail: liuyush@126.com 
ROMISING applied science technologies, like tissue engineering, which is related to interdisciplinary field involving physicians, engineers, and scientists, might give novel tools for surgical procedure. variety of conditions, such organ failure, tissue loss as a result of trauma, cancer abrasion, and inborn structural anomalies, which can be treated by current clinical procedures/surgical methods as well as organ transplantation, including tissue transfer, which could also be use of artificial materials; but, these treatments have potential limitations, as well as organ shortages, injury to healthy components of the body throughout treatment, hypersensitivity, and immune rejection. Recent developments in the rising field of somatic cell science, stem cellassociated growth factors, and regenerative medicine might permit the utilization of stem cells to repair tissue injury and, eventually, to exchange organs.

Stem cell candidates embrace embryonic stem cells (ESCs), induced pluripotent stem cells (iPSCs), and postpartum adult stem cells. ESCs are capable of in depth selfrenewal and growth and have the potential to differentiate into any sort of somatic tissue (1). These traits build human ESCs promising for future use in regenerative medication. iPSCs are derived from differentiated cells like skin fibroblasts and seem to possess an equivalent potential and properties; but, their generation isn't dependent upon a supply of embryos (2). As such, though the therapeutic potential of each ESCs and iPSCs is big because of their auto-reproducibility and pluripotentiality, there are still some limitations to their sensible use: for instance, cellular regulation of tumor formation, moral concerns, and immune considerations related to ESCs, and difficulties with genetic manipulation with regard to iPSCs $(1,3)$. In distinction, postpartum adult stem cells are, by their nature, immune-compatible, and there aren't any moral considerations associated with their use.

Multipotent mesenchymal stem cells (MSCs) are nonhematopoietic cells of germ layer derivation that are present in a variety of postpartum organs and connective tissues. Recently, MSCs are isolated from different tissues including trabeculate bone (4), periosteum (5), synovial membrane (6), skeletal muscle (7), skin (8), pericytes (9), peripheral blood (10), deciduous teeth (11), periodontal ligament (12), and umbilical cord $(13,14)$. Though the stem cell populations derived from these sources are valuable, common issues including low range of harvested cells and restricted quantity of harvested tissues. Therefore, most of adult-derived stem/ progenitor cells need a minimum of amount of ex vivo enlargement or additional manipulation before they're used pre clinically or clinically to satisfy efficaciousness and safety needs.

In distinction, the strong stem cells inside fatty tissue, termed adipose-derived stem cells (ASCs) (15), are one of the foremost promising somatic cell populations known so far, since human adipose tissue is present and simply obtained in massive quantities with very little donor site morbidity or patient discomfort. Therefore, the employment of autologous ASCs as each analysis tool and as cellular therapeutics is feasible and has been shown to be safe and efficacious in diagnosing and clinical studies of injury and illness $(16,17)$. To date, a variety of scientific publications have represented the underlying biology of ASCs, diagnostic studies for the utilization of ASCs in regenerative medicine in numerous fields are performed, and therefore the efficaciousness of ASCs has been determined in many clinical trials. Therefore, the aim of this brief review is to focus on recent progress in ASC biology, trends in diagnosing and clinical studies, and future directions for the utilization of ASCs with specific relevance the field of regenerative medicine.

Adipose tissue consists primarily of fat cells organized into lobules (18). It is a extremely complicated tissue consisting of mature adipocytes, that represent more than ninetieth of the tissue volume, and a stromal vascular fraction (SVF), which incorporates preadipocytes, fibroblasts, vascular smooth muscle cells, epithelial tissue cells, resident monocytes/macrophages, lymphocytes, and ASCs (19, 20). Several articles have shown that a lot of the characteristics of ASCs disagree in keeping with the situation of the harvested fatty tissue. ASCs harvested from superficial abdominal regions are considerably a lot of immune to programmed cell death than ASCs harvested from the higher arm, medial thigh, trochanteric, and superficial deep abdominal depots (21). The density of somatic cell reserves varies inside fatty tissue and may be a function of location, type, and species (e.g., human vs. murine). In white fatty tissue, for instance, ASC yields are larger in subcutaneous depots compared with visceral fat, with a high concentration in arm fatty tissue depots and also the greatest physical property in ASCs isolated from inguinal fatty tissue depots (22). Likewise, it has been reported that ASCs are found within the brown fatty tissue depots found distributed in white fat depots present within the body which they simply endure skeletal myogenic differentiation (23). Phenotypically, the characterization of ASCs remains in its infancy. To date, all makes an attempt to determine a particular definition of the ASC constitution and to discriminate clearly between these cells and fibroblasts are unsuccessful.

The fact that somatic cell yields are bigger from fatty tissue than from other somatic cell reservoirs is another important factor in their quality to be used in regenerative medication. Routinely, $1 \times 10^{7}$ adipose stromal/stem cells are isolated from three hundred milliliter of lipoaspirate, with bigger than $95 \%$ purity (24). In alternative words, the typical frequency of ASCs in processed lipoaspirate is a pair of nucleated cells, and therefore the yield of ASCs is close to 5,000 fibroblast colony-forming units (CFU-F) per gram of fatty tissue, compared with estimates of roughly 100-1,000 CFU-F per $\mathrm{ml}$ of bone marrow (25). Subcutaneous fatty tissue samples are usually be obtained by general anesthesia. Current ways used for analytic 
ASCs go through collagenase digestion followed by centrifugal separation to isolate the SVFs from primary adipocytes. They show a fibroblast-like morphology and lack the intercellular lipid droplets seen in adipocytes. Isolated ASCs are generally expanded in monolayer culture on standard tissue culture plastics with a basal medium containing 100\% fetal bovine blood serum (26).

Previous reports have recommended that the useful effects of bone marrow-derived MSC-based therapy, like growth of new blood vessels, anti-inflammation, and antiapoptosis, are of the most important part mediated by the biological process actions of cytokines and growth factors secreted by the bone marrow-derived MSCs instead of by the differentiation of MSCs into native tissue cell varieties (27). For ASCs, it has been shown that the helpful impact on totally different organs/tissues within the human body may be because of soluble factors made by ASCs instead of their differentiation capability toward different mature lineages (28). The ASCs secretome has the potential to be a strong tool to be used in future approaches to develop cell-/tissue-based therapeutics for regenerative medicine. A number of papers have represented the body secretions profiles of preadipocytes, ASCs, or fatty tissue, which were determined using enzyme-linked immunoabsorbent assays (ELISA) or other techniques $(29,30)$. Analyses of the soluble factors discharged from human ASCs have discovered that cultivated ASCs, at comparatively early passages, secrete hepatocyte growth factor (HGF), vascular epithelial tissue growth factor (VEGF), remodeling growth factor- $\beta$, insulin-like growth factor (IGF)-1, basic fibroblast growth factor (bFGF), granulocyte-macrophage colony-stimulating factor, tumor necrotic factor (TNF)- $\alpha$, interleukin (IL)-6, IL-7, IL-8, and IL-11, adiponectin, angiotensin 1 , cathepsin $\mathrm{D}$, pentraxin, being pregnent zone protein, retinol-binding protein, and CXCL12 (29-31). Moreover, it's also been shown that the soluble factors secreted by ASCs will be modulated by exposure to completely different agents $(30,31)$. Thus, it is going to be that once ASCs are transplanted into inflammatory or ischemic regions, they actively secrete these growth factors, thereby significantly promoting wound healing and tissue repair.

The proliferation capability of ASCs appears to be larger than that of bone marrow-derived MSCs. Previous reports have shown that the doubling times of ASCs throughout the exponent section of growth differ from forty to a hundred and twenty hours $(15,32,33)$ are influenced by donor age, type (white or brown fatty tissue) located (subcutaneous or visceral) of the fat tissue, the subcutaneous procedure, culture conditions, plating density and media formulations $(33,34)$. The younger the donor, the larger the proliferation and cell adhesion of the ASCs is (33). ASCs are usually taken to be stable throughout long culture, because it was according that even ASCs that had passed quite one hundred population doublings had a traditional diploid composition (35). On the other hand, one report suggests that human ASCs endure malignant transformation once passaged for quite four months (36); though recent reports show that spontaneous transformation of MSCs could apparently flow from to crosscontamination with malignant cell lines like fibrosarcoma and sarcoma $(37,38)$. Since the problem of spontaneous ASCs transformation remains contentious, additional experiments and discussion are needed, and careful manipulation of ASCs and long observation of patient's once clinical application are essential.

The proliferation of ASCs may be excited by a single growth factor like FGF-2, EGF, IGF-1, or TNF- $\alpha(39,40)$. FGF-2, specifically, is an efficient growth-stimulating factor and is needed for the long propagation and self-renewal of ASCs via the extracellular signal-related enzyme (ERK) $1 / 2$ communication pathway (41). The proliferation of ASCs can even be excited by PDGF via Jun aminoterminal kinase (JNK) activation (42) and by Oncostatin $M$ via activation of the microtubule-associated macromolecule kinase/ERK and also the JAK3/STAT1 pathways (43). ASCs proliferation is additionally reported to be increased by multiple growth factors, which may embrace any of the single growth factors mentioned on top of supplemented by thrombin-activated platelet-rich plasma (44), human platelet lysate (45), and human thrombin (46). Hopefully, the proliferation of ASCs could be the promising sources of medical use under different stimuli.

\section{CONCLUDING REMARKS}

ASCs are classified as adult somatic stem cells and, as such, their multipotency has limitations compared with ESCs and iPSCs. From a sensible point of view, however, various investigators have examined the practicalities of mistreatment of ASCs in overcoming the limitation within various fields of regenerative medicine. So far, comparatively, few clinical trials during a limited number of analysis areas are conducted to assess the therapeutic potential of ASCs compared with a big amount of printed preclinical studies of ESCs. Additionally, there are many points that stay unclear with reference to ASCs. First, there is proof that the differentiation potential of ASCs might rely upon the anatomic location of the fat and also the donor's gender and age. Second, the key molecular events and transcription factors that originally allot the ASCs to a selected lineage are still unknown, though their lineagespecific differentiation into cells of germ layer origin is well understood at the molecular level. Despite these limitations, ASCs have practical advantages in clinical drugs and their use has become more realistic as a result of adipose tissue, the primary supply of ASCs, is plentiful and simple to get with less donor site morbidity. More preclinical and clinical studies are needed to work out whether ASC-based therapies can fulfill expectations and might be used successfully to treat disorders that current medical and surgical therapies are either ineffective or impractical. 


\section{ARTICLE INFORMATION}

Author Affiliations: Department of Anesthesiology, Obstetrics and Gynecology Hospital, Affiliated to Nanjing Medical University, Nanjing, China (Wu, Liu); Group of Neuropharmacology and Neurophysiology, Division of Neuroscience, The Bonoi Academy of Science and Education, Chapel Hill, NC, USA (Bolick).

Author Contributions: Liu had full access to all of the data in the study and take responsibility for the integrity of the data and the accuracy of the data analysis.

Study concept and design: Wu, Bolick, Liu.
Acquisition, analysis, or interpretation of data:

$\mathrm{Wu}$, Bolick.

Drafting of the manuscript: Wu.

Critical revision of the manuscript for im-

portant intellectual content: Liu.

Statistical analysis: N/A.

Obtained funding: $\mathrm{Wu}$.

Administrative, technical, or material support: Liu.

Study supervision: Liu.

Conflict of Interest Disclosures: The author declared no competing interests of this manuscript submitted for publication.
Acknowledgement: N/A.

Funding/Support: N/A

Role of the Funder/Sponsor: N/A

How to Cite This Paper: Wu H, Bolick ML, Liu $\mathrm{Y}$. The potential use of adipose-derived stem cells. Sci Insigt. 2018; 2018:e000071.

Digital Object Identifier (DOI): http://dx.doi.org/10.15354/si.18.re022.

Article Submission Information: Received, January 09, 2018; Revised: April 03, 2018; Accepted: April 28, 2018.

\section{REFERENCES}

1. Lenoir N. Europe confronts the embryonic stem cell research challenge. Science 2000; 287:1425-1427.

2. Takahashi K, Yamanaka S. Induction of pluripotent stem cells from mouse embryonic and adult fibroblast cultures by defined factors. Cell 2006; 126:663-676.

3. Ben-David U, Benvenisty N. The tumorigenicity of human embryonic and induced pluripotent stem cells. Nat Rev Cancer 2011; 11:268-277.

4. Song L, Young NJ, Webb NE, Tuan $\mathrm{RS}$. Origin and characterization of multipotential mesenchymal stem cells derived from adult human trabecular bone. Stem Cells Dev 2005; 14:712-721.

5. Choi YS, Noh SE, Lim SM, Lee CW, Kim CS, Im MW, Lee MH, Kim DI. Multipotency and growth characteristic of periosteum-derived progenitor cells for chondrogenic, osteogenic, and adipogenic differentiation. Biotechnol Lett 2008; 30:593-601.

6. De Bari C, Dell'Accio F, Tylzanowski $P$, Luyten FP. Multipotent mesenchymal stem cells from adult human synovial membrane. Arthritis Rheum 2001; 44:1928-1942.

7. Dodson MV, Hausman GJ, Guan L, Du M, Rasmussen TP, Poulos SP, Mir P, Bergen WG, Fernyhough ME, McFarland DC, Rhoads RP, Soret B, Reecy JM, Velleman SG, Jiang Z. Skeletal muscle stem cells from ani- mals I. Basic cell biology. Int J Biol Sci 2010; 6:465-474

8. Belicchi M, Pisati F, Lopa R, Porretti L, Fortunato F, Sironi M, Scalamogna M, Parati EA, Bresolin N, Torrente $\mathrm{Y}$. Human skin-derived stem cells migrate throughout forebrain and differentiate into astrocytes after injection into adult mouse brain. $J$ Neurosci Res 2004; 77:475-486.

9. Feng J, Mantesso A, Sharpe PT. Perivascular cells as mesenchymal stem cells. Expert Opin Biol Ther 2010; 10:1441-1451.

10. Shi M, Ishikawa M, Kamei N, Nakasa T, Adachi N, Deie M, Asahara T, Ochi M. Acceleration of skeletal muscle regeneration in a rat skeletal muscle injury model by local injection of human peripheral blood-derived cd133-positive cells. Stem Cells 2009; 27:949-960.

11. Miura M, Gronthos S, Zhao M, Lu B, Fisher LW, Robey PG, Shi S. SHED: Stem cells from human exfoliated deciduous teeth. Proc Natl Acad Sci USA2003; 100:5807-5812.

12. Seo BM, Miura M, Gronthos S, Bartold PM, Batouli S, Brahim J, Young M, Robey PG, Wang CY, Shi S. Investigation of multipotent postnatal stem cells from human periodontal ligament. Lancet 2004; 364:149-155.

13. Baksh D, Yao R, Tuan RS. Comparison of proliferative and multilineage differentiation potential of human mesenchymal stem cells derived from umbilical cord and bone marrow. Stem Cells 2007; 25:1384-1392.

14. Musina RA, Bekchanova ES, Sukhikh GT. Comparison of mesenchymal stem cells obtained from different human tissues. Bull Exp Biol Med 2005; 139:504-509.

15. Zuk PA, Zhu M, Mizuno H, Huang J, Futrell JW, Katz AJ, Benhaim P, Lorenz HP, Hedrick MH. Multilineage cells from human adipose tissue: Implications for cell-based therapies. Tissue Eng 2001; 7:211-228.

16. Gimble JM, Katz AJ, Bunnell BA. Adipose-derived stem cells for regenerative medicine. Circ Res 2007; 100:1249-1260.

17. Tobita M, Orbay H, Mizuno H. Adipose-derived stem cells: Current findings and future perspectives. Discov Med 2011; 11:160-170.

18. Yoshimura K, Suga H, Eto H. Adipose-derived stem/progenitor cells: Roles in adipose tissue remodeling and potential use for soft tissue augmentation. Regen Med 2009; 4:265-273

19. Weisberg SP, McCann D, Desai M, Rosenbaum M, Leibel RL, Ferrante AW Jr. Obesity is associated with macrophage accumulation in adipose tissue. J Clin Invest 2003; 112:17961808.

20. Xu H, Barnes GT, Yang Q, Tan G, Yang D, Chou CJ, Sole J, Nichols A, 
Ross JS, Tartaglia LA, Chen $\mathrm{H}$. Chronic inflammation in fat plays a crucial role in the development of obesity-related insulin resistance. J Clin Invest 2003; 112:1821-1830.

21. Schipper BM, Marra KG, Zhang W, Donnenberg AD, Rubin JP. Regional anatomic and age effects on cell function of human adipose-derived stem cells. Ann Plast Surg 2008; 60:538-544.

22. Prunet-Marcassus B, Cousin B, Caton D, André M, Pénicaud L, Casteilla L. From heterogeneity to plasticity in adipose tissues: Sitespecific differences. Exp Cell Res 2006; 312:727-736.

23. Seale $P$, Bjork $B$, Yang $W$, Kajimura $S$, Chin S, Kuang S, Scimè A, Devarakonda $S$, Conroe HM, ErdjumentBromage $H$, Tempst $P$, Rudnicki MA, Beier DR, Spiegelman BM. Prdm16 controls a brown fat/skeletal muscle switch. Nature 2008; 454:961-967.

24. Boquest AC, Shahdadfar A, Brinchmann JE, Collas $P$. Isolation of stromal stem cells from human adipose tissue. Methods Mol Biol 2006; 325:35-46

25. Strem BM, Hicok KC, Zhu M, Wulur I, Alfonso Z, Schreiber RE, Fraser JK, Hedrick MH. Multipotential differentiation of adipose tissue-derived stem cells. Keio J Med 2005; 54:132-141.

26. Sterodimas A, de Faria J, Nicaretta B, Pitanguy I. Tissue engineering with adipose-derived stem cells (adscs): Current and future applications. J Plast Reconstr Aesthet Surg 2010; 63:1886-1892.

27. Van Poll D, Parekkadan B, Borel Rinkes I, Tilles AW, Yarmush ML. Mesenchymal stem cell therapy for protection and repair of injured vital organs. Cell Mol Bioeng 2008; 1:4250.

28. Kim WS, Park BS, Sung JH. Protective role of adipose-derived stem cells and their soluble factors in photoaging. Arch Dermatol Res 2009; 301:329-336.

29. Rehman J, Traktuev D, Li J, TemmGrove CJ, Bovenkerk JE, Pell CL, Johnstone BH, Considine RV, March $\mathrm{KL}$. Secretion of angiogenic and antiapoptotic factors by human adipose stromal cells. Circulation 2004; 109:1292-1298.

30. Salgado AJ, Reis RL, Sousa NJ, Gimble JM. Adipose tissue derived stem cells secretome: Soluble factors and their roles in regenerative medicine. Curr Stem Cell Res Ther 2010; 5:103-110.

31. Kilroy GE, Foster SJ, Wu X, Ruiz J, Sherwood S, Heifetz A, Ludlow JW, Stricker DM, Potiny S, Green P, Halvorsen YD, Cheatham B, Storms RW, Gimble JM. Cytokine profile of human adipose-derived stem cells: Expression of angiogenic, hematopoietic, and pro-inflammatory factors. J Cell Physiol 2007; 212:702-709.

32. De Ugarte DA, Morizono K, Elbarbary A, Alfonso Z, Zuk PA, Zhu M, Dragoo JL, Ashjian P, Thomas B, Benhaim $P$, Chen I, Fraser J, Hedrick $\mathrm{MH}$. Comparison of multi-lineage cells from human adipose tissue and bone marrow. Cells Tissues Organs 2003; 174:101-109.

33. Izadpanah R, Trygg C, Patel B, Kriedt C, Dufour J, Gimble JM, Bunnell BA. Biologic properties of mesenchymal stem cells derived from bone marrow and adipose tissue. J Cell Biochem 2006; 99:1285-1297.

34. Mitchell JB, Mclntosh K, Zvonic S, Garrett S, Floyd ZE, Kloster A, Di Halvorsen Y, Storms RW, Goh B, Kilroy $G$, Wu X, Gimble JM. Immunophenotype of human adipose-derived cells: Temporal changes in stromalassociated and stem cell-associated markers. Stem Cells 2006; 24:376385.

35. Rodriguez AM, Elabd C, Delteil F, Astier J, Vernochet C, Saint-Marc P, Guesnet J, Guezennec A, Amri EZ, Dani C, Ailhaud G. Adipocyte differentiation of multipotent cells established from human adipose tissue. Biochem Biophys Res Commun 2004; 315:255-263.

36. Olivero C, Lanfredini S, Borgogna C, Gariglio M, Patel GK. HPV-Induced Field Cancerisation: Transformation of Adult Tissue Stem Cell Into Cancer Stem Cell. Front Microbiol 2018; 9:546.

37. Garcia S, Bernad A, Martin MC, Cigudosa JC, Garcia-Castro J, de la Fuente R. Pitfalls in spontaneous in vitro transformation of human mesenchymal stem cells. Exp Cell Res 2010; 316:1648-1650.

38. Torsvik A, Røsland GV, Svendsen A, Molven A, Immervoll $\mathrm{H}$, McCormack E, Lønning PE, Primon M, Sobala E, Tonn JC, Goldbrunner R, Schichor C, Mysliwietz J, Lah TT, Motaln H, Knappskog S, Bjerkvig R. Spontane- ous malignant transformation of human mesenchymal stem cells reflects cross-contamination: Putting the research field on track-letter. Cancer Res 2010; 70:6393-6396.

39. Hebert TL, Wu X, Yu G, Goh BC, Halvorsen YD, Wang Z, Moro C, Gimble JM. Culture effects of epidermal growth factor (egf) and basic fibroblast growth factor (bfgf) on cryopreserved human adipose-derived stromal/stem cell proliferation and adipogenesis. J Tissue Eng Regen Med 2009; 3:553-561.

40. Kras KM, Hausman DB, Martin RJ. Tumor necrosis factor-alpha stimulates cell proliferation in adipose tissue-derived stromal-vascular cell culture: Promotion of adipose tissue expansion by paracrine growth factors. Obes Res 2000; 8:186-193

41. Zaragosi LE, Ailhaud G, Dani C. Autocrine fibroblast growth factor 2 signaling is critical for self-renewal of human multipotent adipose-derived stem cells. Stem Cells 2006; 24:2412-2419.

42. Kang YJ, Jeon ES, Song HY, Woo JS, Jung JS, Kim YK, Kim JH. Role of $\mathrm{c}$-jun $\mathrm{N}$-terminal kinase in the pdgf-induced proliferation and migration of human adipose tissue-derived mesenchymal stem cells. J Cell Biochem 2005; 95:1135-1145.

43. Song HY, Jeon ES, Jung JS, Kim JH. Oncostatin $\mathrm{m}$ induces proliferation of human adipose tissue-derived mesenchymal stem cells. Int J Biochem Cell Biol 2005; 37:2357-2365.

44. Kakudo N, Minakata T, Mitsui T, Kushida S, Notodihardjo FZ, Kusumoto K. Proliferation-promoting effect of platelet-rich plasma on human adipose-derived stem cells and human dermal fibroblasts. Plast Reconstr Surg 2008; 122:1352-1360.

45. Blande IS, Bassaneze V, LaviniRamos C, Fae KC, Kalil J, Miyakawa AA, Schettert IT, Krieger JE. Adipose tissue mesenchymal stem cell expansion in animal serum-free medium supplemented with autologous human platelet lysate. Transfusion 2009; 49:2680-2685.

46. Freyberg S, Song $\mathrm{YH}$, Muehlberg $\mathrm{F}$, Alt E. Thrombin peptide (tp508) promotes adipose tissue-derived stem cell proliferation via pi3 kinase/akt pathway. J Vasc Res 2009; 46:98102. 